\section{Spanish rural society in transition}

\author{
Manuel Pérez Yruela*
}

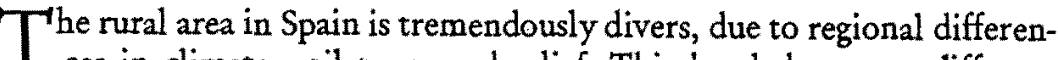
1 ces in climate, soil types and relief. This has led to very different forms of agriculture with contrasting types of production, a corresponding variety in terms of organization of work, use of technology, farming incomes, and the social organization that follows from this. This variety of agriculture has been further accentuated by significant differences in land ownership structures, which result from the historical process by which land has been appropriated.
\end{abstract}

\section{Climate and landscape}

Spain experiences an irregular seasonal spread of precipitation, with a marked summer drought. The variability in rainfall within the Peninsula is in turn quite pronounced. In Galicia and along the Cantabrian coast, precipitation tends to be around $1,000 \mathrm{~mm} /$ year, while in the south-east it varies from 200 to $300 \mathrm{~mm}$ or even less. Rainfall in other regions lies between these extremes, tending to be higher in parts of the Ebro, Duero and Guadalquivir valleys, and lower in the two central plateaux. The lack of rain restricts the productive capacity of the land and the type of crops that can be grown there. In that sense, the greater part of the country is affected by water shortages which can only be offset by means of irrigation, which has always been a crucial issue for agriculture and rural society.

*Institute of Advanced Social Studies (IESA-CSIC), Cordoba, Spain Copyright by the European Society for Rural Sociology. Sociologia Ruralis 1995. Vol. XXXV, No. 3/4, pp. 276-296
Temperatures represent another limiting factor in agricultural production, similarly displaying a wide variation. These differences create clear comparative advantages, favouring regions with milder temperatures and little risk of frost in the development of a more diversified and intensive agriculture. Thanks to these climatic advantages and backed up by increasingly sophisticated technology, important centres of intensive agriculture have emerged on the Atlantic and Mediterranean coasts. Production of strawberries in Huelva, vegetables and subtropical fruits on the Mediterranean coasts of Almeria and Granada, and bananas and some vegetables in the Canary Islands are familiar examples.

Topography is also a critical factor. Spain is a very rugged country: 18 per cent of the surface lies over 1,000 metres, and 56 per cent over 600 metres, imposing significant restrictions on the development of agriculture. High slopes similarly limit cropping and mechanization. Only 12 per cent of the area has slopes of less than 5 per cent. All this means that arable land accounts for only 40 per cent of the total surface area of the country, although the proportion varies significantly from one region to another.

\section{Regional differentiation}

The variety of physical features has brought about considerable regional specialization. Thus along the Cantabrian coast and in Galicia, with plentiful precipitation and very rugged terrain, arable land is scarce relative to meadows and natural pasture lands, so cattle-raising has developed. This extends over the rest of the northern strip of the Peninsula (the north of Castilla-Leon, Navarra, and Catalonia). Although the development of agriculture in all these areas has been hampered by physical factors, very varied production can still be found there.

A totally different type of farming has evolved in the two Castillas, except the northern area mentioned earlier. Extensive crops suitable for dry land as well as those requiring irrigation, both easily mechanized, are common in the Duero and Tajo valleys. Extensive crops are important in both regions, though with differences between them. All are dry-land crops, except for the sugar beet grown in the Duero basin. Due to the limitations of soil and water, dry-land crops are of low yield. Sheep rearing is the most important livestock enterprise in both regions, which together account for 40 per cent of total sheep population.

Intensive agriculture, particularly the production of fruit and vegetables, is concentrated along the Mediterranean coast (Valencia, Murcia and Catalonia) and an isolated inland area in the Ebro valley (La Rioja and part of Navarra), together with part of Andalusia. Navarra, La Rioja, Catalonia, 
Table 1: Farm size (1989) and agricultural population (1991) per region

\begin{tabular}{|c|c|c|c|c|}
\hline & $\begin{array}{c}\text { average } \\
\text { total } \\
\text { area* (ha) }\end{array}$ & $\begin{array}{l}\text { Farm size } \\
\text { average agri- } \\
\text { cult. area } \\
\text { (ha) }\end{array}$ & $\begin{array}{c}\% \text { farms } \\
>50 \text { ha } \\
\text { (agric. area) }\end{array}$ & $\begin{array}{c}\% \text { of total popula } \\
\text { tion employed in } \\
\text { agriculture }\end{array}$ \\
\hline Galicia & 6.2 & 1.9 & 0.9 & 26.9 \\
\hline Asturias & 11.8 & 5.7 & 1.1 & 12.9 \\
\hline Cantabria & 15.9 & 8.5 & 1.7 & 10.4 \\
\hline País Vasco & 14.5 & 5.3 & 3.1 & 2.4 \\
\hline Navarra & 23.5 & 15.7 & 6.4 & 6.6 \\
\hline La Rioja & 17.4 & 7.2 & 2.1 & 10.9 \\
\hline Aragón & 44.6 & 24.6 & 13.3 & 10.9 \\
\hline Catalonia & 22.1 & 9.9 & 7.1 & 3.3 \\
\hline Baleares & 13.3 & 7.6 & 4.9 & 3.5 \\
\hline Castilla-León & 34.3 & 20.9 & 12.2 & 15.9 \\
\hline Madrid & 24.9 & 15.3 & 8.0 & 1.0 \\
\hline Castilla-La Mancha & 33.4 & 21.2 & 10.1 & 15.4 \\
\hline C. Valencia & 6.7 & 2.6 & 1.2 & 7.6 \\
\hline Murcia & 10.8 & 6.3 & 3.1 & 13.2 \\
\hline Extremadura & 32.1 & 25.7 & 8.7 & 20.9 \\
\hline Andalucia & 17.9 & 10.7 & 4.7 & 16.6 \\
\hline Canarias & 5.9 & 1.4 & 0.8 & 6.6 \\
\hline
\end{tabular}

*Includes forests, non-productive land, and land for other uses.

**Arable land, pastures, permanent grassland and land with permanent crops.

Source: Censo Agrario 1989.

in Spain, account for 40 per cent of the total area of open-air, irrigated vegetables. Farming in all these regions calls for greater specialization and familiarity with technology, is more labour-intensive, and requires managerial ability to get perishable produce to markets rapidly. In all these regions, there has evolved a processing industry that attempts to prolong the harvest period of such produce, which has a much more limited season when fresh. A certain export tradition has also evolved. All these things imply the existence of a rural society which is more innovative, and able to adapt to the requirements of the market in order to survive.

Andalusia is the region with the most diversified, and in some respects most productive, agriculture, due to its considerable size and the varied agro-climatic characteristics. It has an extensive mountain region suitable for cattle-raising, and an inland valley, the Guadalquivir, with fertile soils, average rainfall and good temperature conditions, where practically anything can be produced. It also has an important coastal strip which allows out-of-season horticultural production, and also some subtropical crops to be grown, such as avocado, custard apple, sugar cane and pineapple.
Regardless of these possibilities, extensive farming has historically been the most significant in Andalusia. Although little developed in comparison to its potential, intensive crops of fruit and vegetables are also important. Andalusia thus combines traditional agriculture based on extensive crops, and an intensive agriculture (on occasion highly innovative) with much higher valued produce. To give an example, the value of what is produced on approximately 15,000 ha of plastic-covered crops in Almeria roughly equals that of 600,000 ha of wheat, a fact that underlines the importance of this kind of produce. Nonetheless, any further expansion is not easy, since it is limited by market capacity and by competition from other producer countries on the Mediterranean rim.

Every region has consolidated and developed those crops best suited its own agro-climatic conditions. But the productive use of land is not just a question of comparative advantage. It is also related to the subsistence problems of families of peasants and farmers who do not pay much attention to criteria of technical or economic efficiency. The incorporation of agriculture into the capitalist system has extended the use of efficiency criteria, but it is sometimes impossible to put these into practice because of the natural and financial resources available. Alongside specialized production, traditional mixed farming that guarantees a more reliable income and the families' own consumption, therefore persists.

\section{Population}

A good indication of the size of the rural population is the number of people who live in townships of a given size. Thus, those living in townships of less than 10,000, which can, with few exceptions, be considered rural, represented 48 per cent of the total population in 1950 and 24 per cent in 1991. In bigger towns there may be doubts concerning the urban or rural nature of the population. In 1991, 92 per cent of all Spanish townships had less than 10,000 inhabitants, which illustrates the dispersion of a significant part of the population in small centres, with the implications for difficulty of access to particular services, or for the setting up of these in such townships. The agricultural population is unevenly distributed between regions (Table 1). The active agricultural population in Spain declined from 5,237,200 in 1950 ( 48.5 per cent of total active population) to $1,438,200$ ( 9.5 per cent) in 1991 . The agricultural population remains higher than in other EC countries, except Greece, Portugal and Ireland.

According to the 1989 Agricultural Census there were 2,128,407 farm owners, of whom 32 per cent had their main activities outside the agricultural sector. Of the total number of farmers, 32 per cent were over 65 years and in theory retired; 67 per cent of the farmers were over 55. 
which gives a good idea of the ageing of this group. From the point of view of education completed, according to the 1982 Agricultural Census, a very high proportion of farmers with less than 20 ha are illiterate or have no education ( 69 per cent), while the level of education rises as size of farm rises. The 1989 Agricultural Census shows that only 2.5 per cent of farmers have acquired technical knowledge through professional or university training. The remaining 98.5 per cent just gained it through 'practical experience.'

Calculating the real number of employees is not straightforward, since many active residents in rural areas register in employment offices as agricultural workers more because of the absence of jobs in other sectors than because they really do work in agriculture. In 1981 the average number of employed workers in agriculture was 520,600. This figure has decreased in the last fourteen years, being around 330,000 in 1994. According to the Survey of the Active Population, the average rate of unemployment in agriculture (from January to September) in 1994 was 16.1 per cent. This rate is higher among agricultural workers and varies seasonally because most of them are casual workers. Nevertheless, in some months the rate can be higher than 50 per cent. The number of workers with permanent full-time contracts in agriculture was 71,901 in 1989. Despite the difficulties in obtaining exact figures, the essential point is that paid work in Spanish agriculture is very important, especially in the southern half of the country and in the east. In Andalusia and Extremadura alone in 1994 there were almost 230,000 casual agricultural workers drawing unemployment benefit, which is operative only for this kind of worker and for these regions. This figure has not changed much in the last ten years due to the difficulty of these workers finding jobs in other sectors.

\section{Distribution of land ownership and social structure}

The distribution of land ownership is, beyond doubt, one of the most significant variables in the structure of rural society: on it depend the distribution of wealth, inequality and the formation of social classes. Broadly speaking, in the northern half of the peninsula (Galicia, Asturias, Cantabria, the Basque Country, Navarra and part of Castilla-León and the east coast) small and medium-sized farms predominate, while in the southern half (Castilla-La Mancha, Extremadura and Andalusia) land ownership is markedly concentrated.

Table 1 shows the average agricultural area, which is from three to four times less in the North than in the South. The differences become even greater if the indicator refers to arable land or the percentage of large $(>50 \mathrm{ha})$ farms as can be seen in Table 1. This disparity in the distribu- tion of property is rooted in Spanish history, in which the milestones were the reconquest and subsequent repopulation of lands seized from Muslim control between the tenth and fifteenth centuries, and later the confiscations that took place in the nineteenth century. The Second Republic (1931-36) saw an attempt to redistribute property in the areas of extensive estates in the South, by way of the Land Reform Law brought into effect in September 1932. Irrespective of the problems of implementing this law, the ebb and flow of the Republican political process prevented any affective redistribution of property.

In the North there has been a rural society made up of small and medium-sized landowners, with few landless labourers. Social stratification in such rural communities has been based on differences in the size and wealth of their farms. Stratification has not been very extreme, since the differences are not in general terms very great. In the rural communities in the South, on the other hand, great landowners and landless labourers have always lived side by side within a climate of conflict characteristic of class societies.

Based on this landowning structure and with the additional influence of the agro-climatic conditions in each area, several systems of production and land use have established themselves in Spain, which can be classified as follows.

Capitalist farms

The capitalist farm, which has emerged from the conversion of large estates into modern agricultural businesses, is based on increasing use of capital and technology, and totally geared towards market production. These farms rely on regular hired labour. They occur above all in the southern half of the country, but can also be found in Castilla la Vieja, Leon and Aragon.

Traditional extensive estates were, up until the 1950 s, able to organize their farming through the intensive use of hired labour, with scant mechanization and little use of production technology. This was only possible due to the existence of abundant cheap labour and to the technical underdevelopment of Spanish agriculture. From the 1950s onwards, extreme changes began to modify traditional methods of farming. The increase in wages caused by emigration and the generation of jobs in other sectors, along with the availability of technical resources (machinery, pesticides, fertilizers), obliged such farms to increase the use of these resources and decrease use of labour, with the consequent increase in productivity for all the factors involved. Despite the emigration of many day labourers, unemployment remained.

This shift in the use of the factors of production has not. however. 
been accompanied by any significant shift in the way production is geared. Traditional extensive crops are still grown and a few new, easily mechanizable ones have been introduced, instead of gradually bringing in more intensive crops which create more employment. For example, in 1982, 33 per cent of all wheat sown is concentrated on some 14,000 farms of more than $150 \mathrm{ha}$, which represent only 4 per cent of all wheat-growing farms. It is for that reason that seasonal unemployment among day-labourers continues to be a problem. The efficiency of these landowners in their use of available resources, which they could exploit more intensively, has been brought into question.

It is this impression that it is still possible to intensify production on some capitalist farms in the South which lies behind the recent promulgation of a Land Reform Law in Andalusia. Political and legal problems have, however, hampered its implementation. Assuming that these farms are more than $150 \mathrm{ha}$, this type of farming involves 40,251 farms that account for 55 per cent of the total area covered in the 1989 Agricultural Census and 40 per cent of the total utilized agricultural area. Forty-nine per cent of all these farms lie in Andalusia, Castilla-La Mancha and Extremadura. Not all of them can be considered as capitalist farms, since a fair number of them lie in unproductive mountain lands where the process of modernization has not taken place.

\section{Family farming: a diverse category}

The other type that can be identified is the family farm, distinguished by the full-time use of the landowner's labour, part-time work by other members of the family and occasional use of paid labour. We are dealing with small and medium-sized farms, of up to 50 ha approximately in the case of dry-land farming and up to 10 ha irrigated farms. It is difficult to specify exactly what sizes correspond to family farming, since what determines the sufficiency or otherwise of the family labour input on the farm depends not on the area alone, but also on agro-climatic features, availability or otherwise of irrigation equipment and the type of crop. One or two hectares of market garden crops can absorb the labour of the farm owner and whatever family help is available, while the same labour force might cultivate 10 hectares of irrigated land or 40 or 50 ha of dry land with mechanized extensive crops.

For a given agro-climatic zone and type of production, the possibility that a farm can support the family unit depends almost exclusively on the size of the farm. In this sense, there are many family farms of insufficient size. It is not easy to specify the minimum threshold area, since there are great variations from one area to the next. In general terms, for irrigated farming the minimum area may vary from 1 ha (or even less) to $10 \mathrm{ha}$, depending on whether we are dealing with indoor/greenhouse crops, market gardening, vines, fruit trees or extensive crops. In dry-land farming, the figures may vary from 20 to 50 ha, depending on rainfall and the fertility of the soil.

If we take into account the number of farms close to or just below these thresholds, we can estimate how many exist at the limits of survival. According to the 1989 Agricultural Census, there were around 2 million farms of under 20 ha (87.5 per cent of all farms). Not all of these can be considered as below or on the threshold, but the figure does give some idea of the extent of the problem in Spain. However, many of these small farmers supplement their incomes by off-farm work. Only 30 per cent of the farmers with less than 20 ha have their main activity on the farm. This figure doubles for the 20-50 and 50-150 ha ranges, and falls again to 50 per cent for farms of more than 150 ha.

The middle-of-the-range farms of 50-150 ha, which could be regarded as a mixture of family and capitalist farms, number nearly 79,000 . In the light of these data, we can talk of the existence of a well-to-do class of landowners. This is a shrinking group which, up until the time that agriculture began to lose clout in the national economy in the face of the development of other sectors, formed a very significant part of the economic elite of Spain, and had close historical ties with the aristocracy and political power. Their position has been weakened in recent decades through the emergence of other elites with a non-agricultural social and economic base, although within their own immediate environment they continue to enjoy pre-eminence.

There is also an extensive social class based on small family farms, whose survival is made difficult in many cases by lack of capital to expand and modernize their farms. This was the class which, along with the day labourers of the South, began to emigrate on a massive scale in the 1960 s, until the economic crisis and the dramatic rise in unemployment from the mid-1970s halted the shift of labour from agriculture to other sectors. Even though, as we indicated earlier, a significant number of the owners of these holdings no longer farm as their main activity, some who still do so in the less developed agricultural areas (Galicia, part of the Cantabrian coast and all the depressed regions inland) may be considered peasants in a fairly strict sense of the word.

On the east coast, south and Mediterranean coast and in irrigated areas in the interior valleys, there are small farms that have developed into a very dynamic sector of agriculture, specializing in intensive crops with increasing use of advanced technology. The intensification of small farms specializing in cattle raising and fruit crops in Catalonia, market gardening in Valencia and Murcia, the new cases of forced crops in Almeria and part of the Atlantic coast of Andalusia, or the strawberry industry in the prov- 
ince of Huelva, or market gardening on the banks of the Ebro - are the most significant examples. By the way of illustration, 70 per cent of the total area of vegetables grown in Spain is on farms of less than 20 ha. Similar figures can be given for fruit trees and for milking cows, where 72 per cent of the stock is also on farms of less than $20 \mathrm{ha}$.

\section{The transformation of rural society: old and new problems}

Not more than fifty years ago Spanish society was largely rural due to the importance of agriculture on the national economy; the rural and active agricultural population, was more than 50 per cent of the total. The major change in this period has been the de-ruralization and 'de-peasantization' of Spanish society as a whole and as a result, the re-definition of the position and role of rural society today. At the same time, this re-adjustment process has taken place within a familiar framework: urban and industrial development and the development of a capitalist economy progressively incorporated into international economic relations, culminating in Spain's integration into the European Union. What has rural society contributed to this change? What has it received from it? Which rural problems have been resolved, or increased? What is the role and position of rural society? What relationship does it have with the rest of society?

\section{Rural society and social change}

The contribution of rural society to the general process of change has been decisive. In the first place, it has contributed the labour necessary for the development of other economic sectors. This has been possible because poor labourers and peasants were seeking better living conditions and because progressively, the agricultural workforce was released as mechanization and productivity increased in this sector. It also contributed part of the capital needed for the development of other sectors, especially the capital of the biggest and most profitable farms, accumulated when the economy was predominantly agricultural and based on low wages.

Investment from agriculture alone was insufficient. It had to be supplemented with revenues from tourism, with money sent by emigrants from other European countries and with investment from multinationals who had begun to establish themselves in Spain. Finally, during this transformation process, rural society was adapted to satisfy the demands of new consumers. Thus the poorest contributed with their labour, the rich with their money; and those remaining had to undergo an adaptation process, which was often hard.

\section{Irrigation}

The lack of water could only be solved, even partly, through the extension of irrigation. The necessary investments could only be undertaken with state intervention. This problem had already been recognized at the end of the nineteenth century in the debate on the agrarian crisis of 1880 and the re-generation of Spain. Joaquin Costa defended, with a well-conceived vision, the extension of irrigation as the only way to intensify and diversify crops, thereby allowing small farmers to transform their poor unirrigated farming operations and make them more productive. In contrast, the large cereal farmers defended the expansion of extensive unirrigated crops. They finally won and achieved continued support for these crops and protection against cheaper imports from other countries. The choice was complex. The country was deficient in the production of wheat, a problem that was not solved until about thirty years ago, which strengthened the hand of those who defended this option. Probably both were necessary, although it may not have been possible to support both at the same time with the public funds available.

The problem arose again during the Second Republic. An ambitious plan to regulate river basins was proposed, but there was no time to put it into practice. Franco made the great irrigation works one of the showpieces of his policy. Through the National Institute of Colonization irrigation projects were developed over large areas that benefited in particular the large landowners. These projects were also used to create 'colonization villages," made up of labourers who were given small irrigated plots (between 6 and 8 hectares) from land that had been expropriated from the landowners benefiting under the irrigation plans. This policy that Franco came to call the agrarian reform, certainly resolved part of the need for irrigation, yet it did not modify the land ownership structure substantially. In 1950 there was 1.5 million ha of irrigated land. By 1994 this figure had doubled to 3.2 million hectares.

Of the 1.7 million ha of irrigation projects between 1950 and 1994 approximately 1 million were completed through public investment. $\mathrm{Al}$ though the increase has been important, the damage caused by the periodic droughts that Spain suffers, indicates that it is still necessary to improve the system and the regulation of the water available, especially since competition for water by urban, industrial and agrarian users is intensifying. Only 15 per cent of all arable land is irrigated.

\section{The distribution of land}

Inequality in the distribution of the land is another historical problem which has not been solved during the process of change. Emigration and 
the shift of the population from rural to industrial zones has helped to alleviate slightly and indirectly solve such problems. Census data for 1962 aid 1982 show that there has been a considerable drop in both the number of farms and the total arable area. The total arable area in 1982 was 6.8 per cent less than in 1962 (Ruiz Maya 1987). The total number of farms has dropped by 15.6 per cent involving particularly farms with less than 50 ha. The disappearing smaller farms free land, which is incorporated into larger ones. It seems, therefore, that inequalities in farm size distribution are gradually being reduced. This has been possible because emigration, retirement or other factors have caused farm owners to give up their farming operations. It is necessary to wait until the next census to see whether this trend is continuing, and with what intensity.

Labour emigration in the South has reduced the magnitude of the social problem. Although considerable numbers of agricultural workers are still present, they continue to be faced with the problems of seasonal unemployment. This situation has been alleviated with the special agrarian unemployment protection in Andalusia and Extremadura. This cannot be a final and socially acceptable solution, but it will not be easy to find an appropriate solution in the next few years. It is a persistent social problem that has not been directly tackled up until now. It is not feasible that the present productive structure of Andalusian agriculture could create more employment in the short term. The intensification of production is not an answer because markets cannot shift more agricultural goods, neither is easy to open new markets. On the other hand, the country lacks a welldeveloped industrial sector that could absorb workers from agriculture.

Neither the Franco agrarian policy, nor the successive democratic governments from 1977 onwards, have had the intention of tackling the questions of large-scale land ownership. The only exception is the attempt at agrarian reform in Andalusia. The existence of large estates has progressively acquired certain social legitimacy through the level of efficiency achieved in the production of extensive crops. The social dimension of the problem has diminished when compared with other national problems. Furthermore, agriculture and rural society have also been losing importance within Spanish society compared to the new and serious problems that have arisen (economic recession, de-industrialization, industrial reconversion and high unemployment). Even the criticism of the under-use of resources due to the lack of intensification of large-scale farming operations, can be countered by the argument of limited markets. The historic solution of a simple redistribution of the land and wealth through an agrarian reform is possible in theory. Yet in the present context, such a proposal would face serious social, political, economical and even practical difficulties in its implementation.

No agrarian policy measures have been taken to resolve the problem posed by the insufficient size of farms, either the issue in this case is composed byall farms is very difficult as pletely different. To increase the size of small farms is very difficult as there is no extra land available. From the 1970s onwards, a new policy began aimed at the concentration of plots of land. This policy was intended to increase the size of farms but its actual effect was only to reduce the number of dispersed plots that made up the small farms. The excessive froch manization and rationalization of work fragmentation of land made the mechanization and rationalization of work on these farms very difficult. The size of small holdings began to increase when the land was freed by emigration, retirement or abandonment by small landowners. This meant that remaining farmers could incorporate this land into their farms through leasing and buying. Therefore a spontaneous process of land concentration had occurred, aided by the changes occurring in Spanish society and which were not induced directly by the agrarian policy.

\section{Technological developments in agriculture}

What probably has been more influenced by agrarian policy and state intervention in recent years, has been the increased level of technology in agriculture and the re-orientation of production. The creation in 1955 of agriculture and the re-orientation of prod to diffuse among younger and less educated farmers a technology that, although perhaps not the most sophisticated, needed to be applied in agricultural operations. In spite of the criticisms that can be made about this institution, it achieved advantages for rural society. In any case the process of disseminating technology amongst farmers had other aspects. The companies producing and selling machinery, fertilizer, seeds and pesticides used technological advice to the farmers as a strategy for promoting their products. Despite the quality of farmers as a strategy for prom to increase farmers' knowledge and the use of the technological resources that they offered.

Some figures give an idea of the magnitude of the changes that have occurred. Between 1960 and 1991 the consumption of fertilizers tripled, although Spain still consumes only half as much fertilizer as Italy and only although Spain still consumce. Currently the national production of fertilizer meets practically all the consumption needs. The mechanization index $(\mathrm{HP} / 100 \mathrm{ha}$ ) for 1960 was 9.9 , rising to $269.9 \mathrm{in} 1991$. It has been pointed $(\mathrm{HP} / 100 \mathrm{ha}$ ) for 1960 was 9.9 , ring necessary for their needs. This would not have happened if the machinery necessary for their needs. This would not hachinery stands as a modernization, welfare and progress symbol for farmers, which often causes them to tion, we fare and progess a appreciate its symbolic more than its real value. This trend has been favoured al fuel. In 1986, this assumed a total of 38,500 million pesetas. 
Whentess, it cannot be said that the technical problems in agriculwandere been completely solved. In regard to the intensive agricultural stem;exterior technological dependency is still very strong. Seeds, crop thection products and elements of infrastructure are supplied mainly by the multinationals. Even in solving the technical problems of the most traditional agriculture, problems exist. Agrarian research in Spain is still insufficient compared with other EU countries and we lack a good research network to help farmers in decision-making. Links between agrarian researchers in the universities, state research centres and farmers and their day-to-day technical problems are still very weak. Since there are sufficient researchers and experimenters in the country, it is difficult to explain why these links do not exist. There is an impression that Spanish research policies have produced a 'breakthrough' mentality, induced by the false assumption that we could be competitive in a short period in key sectors of research, forgetting that there is still much that could be done in less spectacular but more necessary areas.

Changes in agrarian production

State intervention has also played an important role, through agricultural price policies, in changing the direction of Spanish agricultural production. The need for rural society to become the supplier of foodstuffs and of labour in the process of economic development that was started in the 1970 s, was the main concern of agrarian policy at that time. This was indicated in the 1962 report by the International Bank of Reconstruction, Economic Development in Spain.

Both the first (1963) and the second (1968) Development Plan of the Franco era, set these among the main objectives for state intervention in the agrarian sector. These Plans included agrarian policy measures to solve all imaginable problems in rural society. Nevertheless, the most importan aims were to adapt agrarian production to the new social demands, to achieve the highest possible level of self-sufficiency in food production and to facilitate the shift of rural population towards industrial and service sectors. From then until now, rural society has been adapting to its new role. The pattern of production has changed. The area under wheat dropped between 1965 and 1994 by something more than 2 million ha (48 per cent), yields increasing over this period from $11.1 \mathrm{gm} / \mathrm{ha}$ to 24.6 $\mathrm{qm} / \mathrm{ha}$. This freed land has been used for barley, necessary for animal feed and also for increasing protein of animal origin. Within the same period the barley area has increased from 1.3 to 4.4 million ha and yields have risen from 13.8 to $21.0 \mathrm{qm} / \mathrm{ha}$. The area under pulses for human consumption (beans, lentils, and chickpeas), the staple foodstuff for so many years, has dropped by 60 per cent.
Products in greatest demand in developed societies have increased quite a lot during the period. Vegetable production has doubled, milk has increased nearly five times and eggs three times. The real transformation in the eating habits of the Spanish has been in the consumption of chicken and pork. Chicken production has multiplied by nearly sixty times during the period and porc has increased six times. Beef and real production during this period has only increased about three times.

In spite of these changes, rural society has been declining relatively in both demographic and economic terms. In 1960, agriculture contributed 22.7 per cent to the Gross National Product and in 1992 only 3.8 per cent. Even in regions such as Andalusia, where agriculture is still an important economic sector, this figure currently fluctuates around 6 per cent. Nevertheless, agriculture provides enough food and raw materials for the country's needs, except for wood and soya that we need to import to a great extent. The export/import ratio has been around 88 per cent during the last decade. Farm productivity has also increased. The gross value added per labour unit in agriculture increased by 29 per cent between 1986 and 1991.

\section{Agricultural incomes and prices}

Rural society and agrarian activity have a clear asymmetrical dependency relationship with the rest of society. The solution of many of their problems depends upon the evolution of other economic sectors. Also, they have to buy the majority of their inputs from other sectors. Furthermore, the sale of a large part of their products depends upon agro-food industries and distribution companies who consider farmers to be mere producers of raw materials. On the other hand, agricultural prices still have an important impact on the food component of general price rates in the cost of living, necessitating strict control on prices in order to avoid inflation. This has systematically divorced the prices that farmers receive for their products from what they pay for inputs, to the advantage of the latter.

Between 1976 and 1986 farm product prices grew by 181.3 per cent and input prices by 226.3 per cent. From 1987 to 1991 , the former grew by 13 per cent and the latter by 12 per cent or 31.2 per cent, depending on the types of goods considered. Year to year this imbalance may have been less, and in some years actually reversed. The general trend however is for farmers' incomes to suffer a systematic erosion. This problem is particularly serious for small farmers who cannot adjust easily by increasing the area they cultivate, changing the products they grow, or changing the production volume. Product prices guaranteed by the state during those years, were uniformly set for all farmers, irrespective of farm size or productivity of farming operations. Inevitably this proved more advantageous for the larger farms that enjoyed economies of scale, with more intensive use of 
thical factors of production. It also benefited those enjoying compativeadvantage through better agro-climatic conditions or infrastructure (Frigation, for example), or both. The cost-price squeeze has also affected warkers, whose wages have increased less than others. Between 1976 and 1986 agricultural wages grew by 369 per cent compared with 417 per cent in non-agricultural occupations.

The dependency situation in the economic field has links with politics. This can be seen in two closely related aspects. Within the general objectives determined by the political system, those related to rural society and agriculture have changed substantially. If in the 1960s the concern was how to induce the agrarian sector and rural society to contribute to Spain's capitalist development, today there are few who believe that continued development depends on agriculture. Therefore, according to this view, what is important is to maintain the present system of articulation and make sure no additional problems are created. Thus, the current tendency is towards maintaining the status quo, or policies that prevent new problems from surfacing (for example the EU measures to abandon cultivated land) or support in social rather than economic terms. Rural society and agriculture definitely no longer appear as a priority on the political agenda. Naturally this does not satisfy the farmers, who no longer have the electoral power to influence programmes and political decisions.

\section{Changes in rural society: winners and losers}

Yet the democratic transition has brought important changes in rural society. For the first time, in many decades, with the brief exception of the Second Republic, it has been possible to break the patronage system that gripped rural communities. Moreover, local political power has passed out of the hands of the largest local landowners, who traditionally held it. This has occurred throughout Spanish society, but has had particular relevance in rural areas, where the dependency relationships, submission and social control are more intense than in urban areas. Therefore, this change has more than an abstract and ideological value. It has meant a liberation that has renewed and refreshed social daily life in a way that is more intense and closer to people than in other places. This does not mean that the mistrust, the shrewdness, the dependency relationships characteristics of these communities have completely disappeared, since it is unlikely that this could happen whilst the structural and cultural bases that produce it still exist. Furthermore, new problems have arisen provoked by the inevitable frictions created by political differences. These problems are more visible and less easily diffused within small groups. Yet all this does not negate the generally beneficial effects that the democratic transition has produced at local level.
A process of dual development characterizes the development of Spanish rural society. A comparatively impoverished sector compared to the rest of Spanish society, is made up of small farmers, peasants, labourers and the large numbers who live in disadvantaged areas. Combined with this, there exists the other side of rural society, much smaller in size, which has been able to adapt itself to the changes and develop profitable farms which, in some cases, provide with high income.

From another point of view, the transformations that have occurred within the whole of Spanish society have had an ambivalent effect on rural society. The educational system at primary and secondary levels and professional training now extend to the major part of rural areas. Even with short journeys from the smallest to the largest centres, the school-age population can today attend relatively easily. University access is more difficult due to the costs involved. The increase in the number of universities (there is more than one university for every two provinces) has improved the situation, although there is still a minority of university students coming from poor rural areas.

The Social Security system has extended complete coverage to the agrarian population. The budget of the Social Security Special Programme has increased by 13 per cent between 1979-85 and 40.9 per cent between 1976-79. An important part of the budget is covered by state transfers that contributed 86 per cent of in 1992, compared with 14 per cent contributed by workers and landowners. This gives an idea of the magnitude of the economic support that the agrarian population receives from other sectors. The number of workers (self-employed and employees) affiliated to the Social Security has decreased by 26 per cent. In the same period the number of pensioners went increased by 5 per cent. The ratio of workers to pensioners has varied from 1.05 in 1985 to 0.75 in 1992. In the same year this ratio was 1.88 for other sectors. This partially explains the need for large financial transfers from the state to cover the budget of the Special Agrarian Programme. Equally a special unemployment benefits scheme has been created for casual agricultural workers in the South.

Although up until a few years ago, specialized health care was centralized in the provincial capitals, with the resulting inconvenience for residents in rural areas, this service has also recently begun to be extended to the rural population through local health care centres and county hospitals. Finally, following democratic elections in the town halls, new corporations have made visible efforts to equip their towns with sports centres, regulate urban development, improve services and promote leisure activities and culture, within the small budgets that they have.

These are generally positive aspects that have benefited rural society as never before, but the negative aspects and the economic and social costs that have arisen due to this transformation process are no less important. 
2.

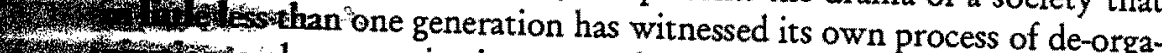

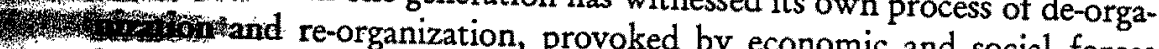
and control and with little consideration to the problems for the
findayers involved thin players involved.

External and internal emigration, bringing serious psychic, cultural and economic problems for adapting to new environments and the widely-held but often impossible dream of returning to their own social roots, have caused suffering that has left its mark on millions of Spaniards. The impoverished small landowners who have had to fight a hard and losing battle to survive on their farms without the help of their sons who have emigrated represents a generation of solitary elderly people, who wearily pursue a traditional way of life that they know will end with themselves. Just as well that at the end of their lives they will benefit from the pension plan that will help them to retire with something less of an economic burden.

On the other hand, medium or even large-scale landowners, who under the traditional agricultural regime maintained pre-eminent economic and social status in their communities, today have only the memory of such times. Hidalgos of the twentieth century who did not know how to adapt to the changes, thought that their formerly affluent way of life would continue in spite of divisions for inheritance and new economic conditions. Together with them, are those who by their own efforts or by inheriting land have managed to continue to live comfortably or in luxury, but now have to share their social position with a newly created middle class, especially in the largest centres, formed by professionals, civil servants, workers, shop owners or small industrialists.

\section{The decline of traditional culture}

In recent years much of rural society has lost its isolation. With this opening up, its specific cultural characteristics have been transformed. Emigration has contributed to this. Those who formerly lived in rural areas have made contact with another culture, which they have assimilated more or less completely. They have brought their experiences to their communities of origin by means of family contacts and periodic visits.

The media also, especially television, have invaded rural communities, showing them the nature of the increasingly complex society to which they belong and the variety of values and standards of behaviour that exist within it. In the summer months, especially when emigrants return to their communities of origin, certain scenes reflect these exchanges. Together with the traditional festivals that punctually summon both those who have left and those who stayed behind, that still perform a community identification function, there can be seen fashions of dress, consumption and enjoyment which are not very different from those seen on any festive occasion in towns where the emigrants gather. In winter, the rural community finds itself alone again with its daily routine, yearning for those restless days, inable to escape the effects of this transitory and repeated immersion in a different life experience.

In rural society the instrumental, selfish and commercial rationality of capitalist culture is spreading. This has been almost imperative for survival, a response to integration into the market economy. The concept of ' $\mathrm{farm}$ ing as a way of life' has been undermined. The importance of home consumption, of maintaining and preserving the 'home,' as the heritage to sustain the family and on which its future depends and the consideration of the family as a labour resource on which the strategy of adjustment and continuity of the 'home' is based, have diminished to a great extent. This also implies the retreat of traditional rural values associated with it. The extended family is no longer the dominant model and marriage as a strategy to reunify or enlarge the inheritance is also going out of fashion. These changes have been significant among the small and medium-sized landowners. The large landowners have already started to adapt themselves culturally and economically to such rationality. The impact of these changes has been uneven, whole areas and dispersed disadvantaged areas remaining which are still at an empty stage.

\section{Conclusion: new models of rural development}

Spanish agriculture as a whole is a relatively efficient sector, able to feed the population. In spite of this, a few problems remain. In first place, improvement or eradication of rural poverty demands more than mere social assistance or new waves of migration, which have resulted in depopulation of extensive areas of our territory, with associated damage to the countryside and nature. The maintenance of decent living standards for the population in these zones needs special measures like those already in place in the EU for mountainous and disadvantaged areas, and measures to encourage the development of small firms making use of the resources in each zone, to offer alternatives to farm work.

Where rural society has been able, with state aid, to solve the problem of raw materials and food production, its present problems are related to its capacity to adapt to other changes. The food processing and distribution industries have acquired more importance than mere production. Farmers begin to see themselves as subject to new dependency relationships. This sector also consists mainly of multinational companies. In the export of fruit and vegetables, so important in Spanish agriculture, growers have not yet succeeded in organizing themselves in international markets 
asto retain value added from marketing. The solution to these probleass is not easy and we may have reached irreversible dependency in some situations. Finally, incorporation into the EU and the Single Market is going to open a new competitive front for agricultural products in Spain, to the detriment of those which, for various reasons, productivity in Spain is inferior to other countries.

Thus it could be said that while the change which has occurred in agriculture and rural society is important, the agrarian sector is only halfway incorporated into the Spanish and European market economy. Yet the situation is not unique to this sector, it applies elsewhere and to Spanish society in general. All this goes back to the late incorporation into capitalist development and democracy and to Spain's marginal. It is not easy to cope with an agrarian structure polarized between a minority of viable and profitable farms and a majority of small ones always needing support to survive.

The evolution of agriculture in recent decades has led to a situation that demands new strategies and models of rural development. The success of policies that were implemented to help solve the crisis of traditional agriculture has significantly increased productivity and given rise to a problem of surplus in production, land under cultivation and workforce. The environmental problems created in the process also require restrictions on the use of some inputs. The new framework of international trade relations and the reform of the Common Agricultural Policy are gradually giving way to an agricultural policy which tends to broaden international competition and do away with restraints that obstruct free competition in the market, altering the system of subsidies granted to farmers up till now.

In this setting, farmers will find it difficult to maintain adequate margins of profitability and returns on their factors of production. Any further reduction in the employment in agriculture will have to be imposed on a workforce already scarce in many areas. If this reduction involved a new exodus from rural to urban areas, not very likely at the present time in Spain, it would have undesirable consequences of depopulation in quite a few areas. It would undermine the presence of man as an indispensable agent in the conservation of the rural environment and landscape, cultural and archeological heritage. Without such an exodus, problems of poverty, relegation to the fringe of society, and a further deterioration of living conditions in rural areas may well arise.

Solutions based on subsidies and the transfer of resources, especially made without requiring any kind of service in return, neither could nor should form the only remedy. The maintenance of a certain social and economic vitality that would reverse the decline in the attraction of these areas for economic and residential development, calls for a return to the notion of rural development and for policies that will promote it.
Rural development must be based on new models which cannot rely on raditional agricultural activity alone. Farming can continue to supply resources for complementary activities that generate added value. Furthermore, it will be necessary to promote the setting up of non-agricultural more, it will be necessary to promote the setting up of non-agriculturat production and service activities, taking advantage of unexploited tradi-
tions, resources and experience. The local approach to development can assist in this process.

Small farms have started to develop different survival strategies. Dedication to so-called biological agriculture, specialization in niche products of tion to solalled biof creation of high quality, complementing farm income through craft work, creation of small companies or the development of tourism. The solution to the prob lem of small farms points in this and other similar directions, which the EU wants to promote to avoid the demographic problems described earlier. All these changes converge with the new conception of rural developer. All the chat be wise to pay ment that must be adopted for the not find us, as usual, unprepared.

\section{Bibliography}

Arnalte Alegre, E. (1985) Modos de producción en la agricultura española. Madrid. Instituto de Estudios Agrarios, Pesqueros y Alimentarios

Bernal, A. M. (1988) Economía e bistoria de los Latifundios. Madrid: Instituto de Espasa-Calpe

Castillo, J.J. (1979) Propietarios muy pobres. Sobre La subordinación política del peque ño campesino. Madrid: Servicio de Publicaciones Agrarias del Ministerio de Agricultura

Ceña Dełgado, F. et al. (1985) Características y efectos sociales de la política agraria española (1964-1984). Pensamiento Iberoamericano (8)

Ferrer, M. et al. (1988) El sistema de población urbana y rural de España. Papeles de Economia Española (34)

García Delgado, J.L. eds. (1976) La cuestión agraria en la España contemporánea. Madrid: Cuadernos para el Diálogo

García Sanz, A. and R. Garrabou eds. (1988) Historia agraria de la España contemporánea. Barcelona: Crítica

Malefakis, E. (1971) Reforma agraria y revolución campesina en la España del siglo

XX. Barcelona: Ariel
Moyano Estrada, E. (1984) Corporativismo y agricultura. Asociaciones profesionales y articulación de intereses en la agricultura española. Madrid: Instituto de Estudios Agrarios, Pesqueros y Alimentarios

Naredo. JM. (1971) La evolución de la agricultura en España, Barcelona: Estela

Ia Nueva Agricultura Española (1985) Papeles de Economia Española (16)

Pérez Yruela, M. and Gómez Benito, C. (1990) Rural Sociology. In S. Giner and M. Moreno eds. Sociology in Spain. Madrid: CSIC

Pérez Díaz V. (1972) Estructura social del campo y éxodo rural. Madrid: Tecnos

Pérez Touriño, E. (1983) Agricultura y capitalismo. Análisis de la pequeña producción Pérez Touriño, E. (1983) Agricultura y capitaltsmo. Analisis de La pequeña producción 

W 3 midad ante desarrollo agrario. Agricultura y Sociedad (47)

T. Jprez Zuniga, M. and R. Soria Gutiérrez eds. (1985) Lecturas sobre agricultura - fomiliar. Madrid. Instituto de Estudios Agrarios, Pesqueros y Alimentarios S. Maya I (1987) Evolucion de la concentracio de la iera (1962-19 Agricultura y Sociedad (44)

Sevilla Guzmán, E. (1979) La evolución del campesinado en España Barcelona: Península

Sumpsi, J.M. ed. (1988) La reforma agraria andaluza. Madrid: Centro de Estudios Constitucionales 